\title{
The grant-writing process
}

\section{A learning experience}

\author{
by Aparna Zambare
}

$I^{2}$ always thought that grant writing was not my cup of tea. However, a recent grant-writing experience changed my earlier discomfort into a realization that grant writing involves a set of skills, which can be acquired with practice and persistence. In this article, I will share what I learned from that experience.

My grant writing story has neither a happy nor an unhappy ending; it lacks closure, at least at this point. Some funding agencies to which I sent the grant have rejected it and some others have not given their decision. Although the entire process of researching and writing the grant, selecting funding agencies and sending the proposal, dealing with uncertainty, accepting rejections, and still going on with renewed hope has been stressful, it has also been educative.

\section{Beginning}

This grant-writing process began some time after I joined Central Michigan University (CMU) in Mount Pleasant, Michigan, as reference librarian and English bibliographer about two-and-half years ago. The position was vacant for a while so when I joined, I started talking with the faculty of the English Department about their needs and expectations from the library. In my conversations with children's literature professors, the issue of cataloging some classic children's literature books in the CMU Libraries ${ }^{1}$ came up. The faculty asked me to see if there was a way to address this issue.

\section{Researching the problem}

Cataloging classic children's literature books has been a chronic ailment in our library. So I knew that finding a cure for it would be a long, multistep process, and that I would need to make many decisions along the way.

I started by studying the background and collecting data to get a clear picture of the problem and the need for the project. At CMU, children's literature is a core element of the English Department and Elementary Education program curricula. To support these programs, the CMU Libraries have collected a rich array of children's books, including fiction, nonfiction, textbooks, journals, maps, films, computer programs, and bilingual texts located in the Instructional Materials Center (IMC), a branch library, which is housed in Ronan Hall, on another part of the university campus.

Unfortunately, a very large portion of this collection (especially, the older books that arrived before 1991—approximately 28,500

\section{About the author}

Aparna Zambare is reference librarian and English bibliographer at Central Michigan University, e-mail: aparna. zambare@cmich.edu

(c) 2004 Aparna Zambare 
titles) is currently accessible only through an in-house database called the Winnebago system. There is no Web access and no integration with the libraries' online catalog. Access is limited to two patron search workstations located near the collection. This creates an obstacle for our off-campus students, alumni, faculty, and even our on-campus students who are unable to visit the IMC in person for their research.

There are also many other potential users in the surrounding community, including high school students, classroom teachers, children's librarians, public library users, and aficionados of children's literature with whom we are unable to share this rich collection through interlibrary loan. If cataloged electronically and transported into CMU's shared integrated library system (ILS), we could share these resources with a much greater number of users.

\section{Preparing to write}

This genuine need and request from the faculty inspired me to write a grant for this project. But before writing, it was necessary for me to do a lot more groundwork. In the past, two attempts were made to obtain grant money, but without luck. So this time, I wanted to make sure that I followed every grant-writing step systematically.

I first talked with my supervisors, who welcomed the idea and encouraged me to proceed. I then talked with a grant recipient in the library for advice. I also gathered ideas and insights from books and articles on how to write a successful grant proposal. ${ }^{2}$

These ideas and insights helped me map out a rough action plan for writing the grant. Accordingly, to gain first-hand knowledge of those older titles, I visited the IMC with the head of collection development and a cataloging specialist. We reviewed the in-house database and shelf list cards, and randomly checked some monographs to see what bibliographic information they contained. We found that some titles were very old and their bibliographic records were quite inadequate, preventing their simple transfer into the Libraries' ILS. The visit thus reinforced the need for purchasing those bibliographic records from the Online Computer Library Center (OCLC).

At this point, we considered two options for producing bibliographic records and settled on hiring temporary staff, having them examine each piece by hand and record the detailed information about each piece, and downloading records from OCLC. Although time-consuming, we thought, this option would be the least expensive and would allow for the acquisition of the best-quality bibliographic records.

The other option was the retrospective conversion of the shelf list into computerized records, which then could be transferred into the ILS. This was problematic because of the minimal cataloging information available on most records and the fact that, in many cases, staff might still need to examine the piece to complete their work. This research and stepby-step approach enabled me to choose the best option and to have greater control over my materials, which eventually helped me in writing the grant and answering the queries made by various funding agencies.

\section{Working out parts of the grant}

My next step in grant-writing preparation was to ascertain the objectives, timeline, and budget and develop an evaluation plan. So to collect specific details on the workflow process, I talked with our database specialist and systems librarian and came up with specific activities for processing information from each book into the libraries' database.

The main activities included recording existing bibliographic information on each piece, downloading complete bibliographic details from OCLC into the CMU Libraries' catalog, and attaching the libraries' holding symbol to the record in OCLC. Each activity was further broken down into subactivities. Next, we prepared a time sheet and a budget allocation table for the project, calculating the time and budget for processing each title and then multiplying that by the total number of books to present the big picture. 
Additionally, since many foundations ask the grant requester to share the cost of the project-often in kind and not in cash-I also prepared a separate table providing the particulars of CMU cost share, in consultation with the libraries' business manager. This mainly consisted of personnel cost, office supplies, and on-site facilities. When preparing statements on project activities, objectives, timeline, and budget, specificity is the key. The more details you provide, the better idea the funding agency gets about how its dime is going to be spent.

Further, I needed to prepare the evaluation plan. Many funding programs want to have a clear idea of your plans to evaluate the results of the project before they make a decision; some of them even expect you to conduct a formal outcome-based evaluation survey and submit the conclusions to them at the end of the project. Since our project was about increasing access to the IMC collection and making the books available to statewide and nationwide users through interlibrary loan, comparing pre- and post-user statistics from the ILS seemed to be an appropriate tool for measuring the project outcome.

\section{Seeking support}

After getting all this groundwork done, I met with many people concerned with the collection to discuss the action plan and seek their support. I talked with children's literature professors and the associate dean of the College of Humanities and Social and Behavioral Sciences (who also teaches children's literature). They offered positive feedback on the plan, provided pertinent information on their courses and students, and actively supported the project by writing letters. Students played a significant role in offering support to the project, since they knew exactly where the shoe pinched. Some of the students, both current and past, articulately pinpointed their difficulties in accessing the collection. Everyone that I talked with and sought support from was overtly positive. Help and appreciation indeed came from all quarters.

\section{Writing, sending, and waiting}

I put together various parts of the grant and attached supporting letters to it. In consultation with CMU's Development Office, I selected six foundations that were good matches for the project. Located in different states, each foundation had its own guidelines and proposal-reviewing procedures; some of them were looking for a two-page letter while others were looking for a much longer narrative, which made grant writing quite a challenging job. I customized my grant to suit each foundation's requirements, to convince them of the validity of the project and its relationship to their agenda.

Each version of the grant proposal appeared like a persuasive essay in itself and involved a good deal of writing skill. I finalized my draft proposals by reading them several times to check and correct any vague areas, typos, or grammatical errors, and by asking a couple of colleagues to review the proposals. After completing some paperwork, I mailed the grants; thereafter came a period of waiting and anxiety.

Unfortunately, four foundations have rejected the proposal so far: two of them have mentioned that the competition was unusually tough this year due to the current economic crisis in the country, while two others have not furnished any reasons. I was disheartened to see that at the end of the tunnel, there was no light. Theoretically, the request is still pending with two more foundations, so there is still hope.

Also, earlier this year, I learned about a federal grant program, which I thought was the best fit for the project. So, once again, I worked on the grant and sent it with help from CMU's Office of Research and Sponsored Programs. And once again came a period of anxiety.

\section{Growing with the experience}

Looking back at the entire grant-writing experience with a somewhat detached frame of mind, I believe it was not just hard work resulting in nothing but frustration. I have learned something in the process. I have learned about such areas of librarianship as retrospective conversion, the Winnebago sys- 
tem, and other cataloging activities previously unknown to me. Although I was familiar with the ILS system from having used it, the code z39.50 was a new piece of knowledge for me. Moreover, this experience has made me realize the need for establishing a dialogue among various areas of the library and learning from each other's experiences.

This was not my project alone; it was a collaborative act. I took responsibility for writing the grant and, for that reason, pulling together information from relevant groups, such as students, faculty, deans, librarians, staff, cataloging and systems specialists, university offices, and foundations. However, in so doing, I realized that I work well with a team of diverse people to constructively coordinate a project; I not only developed good professional relationships but also friendship with some of them.

I think my initial apprehension about grant writing came from my unfamiliarity with this path, but I am glad that I took it; I accepted the challenge, studied the problem, and wrote a competitive grant. Although I am disappointed with the end result, I am also happy with what I have accomplished so far in the process. On the whole, I must say grant writing has been a positive and growing experience for me.

\section{Notes}

1. A group of six libraries at CMU, including the University Library (Park Library), Clarke Historical Library, Media Services, Instructional Materials Center, Music Resource Center, and Off-campus Library Services. Please visit www. lib.cmich.edu for more information.

2. See: Jim Burke and Carol Ann Prater, I'll grant you that: A step-by-step guide to finding funds, designing winning projects, and writing powerful grant proposals (Portsmouth, NH: Heinemann, 2000); Jeffrey A. Falkenstein, National guide to funding for libraries and information services, 7th ed. (New York: Foundation Center, 2003); and Ada A. Jarred, "Adventures in grant-writing: Northwestern State University of Louisiana." CERL News, no. 10 (1990): 955-7. 